DOI https://doi.org/10.18551/rjoas.2018-09.26

\title{
ROLE OF SOCIAL CAPITAL IN RESOURCE MANAGEMENT FOR INCREASING CIBULAO HAMLET COMMUNITY ECONOMY AT BOGOR, WEST JAVA PROVINCE OF INDONESIA
}

\author{
Guswandi \\ Faculty of Economics, University of Krisnadwipayana, Jakarta, Indonesia \\ E-mail: guswandi@unkris.ac.id
}

\begin{abstract}
The community welfare level in an area is not merely to be interpreted as the level of economic growth, productivity, material advancement. It ought to consider the socio-cultural performance, such as social interaction, access to income, education, health and the democratic process. Cibulao Hamlet, Tugu Utara Village, Cisarua district, Bogor Regency, Indonesia, are intriguing examples of efforts to develop community independence while paying attention to social capital development. This study endeavor to determine the role of social capital in Cibulao Hamlet in improving the community economy using explorative and descriptive methods. The research was conducted to determine the socio-economic condition of the community. Research result indicates that existing social capital in Cibulao Hamlet can gradually improve the community economy.
\end{abstract}

\section{KEY WORDS}

Social capital, resources, management, community, economy.

In an effort to improve socio-economic development, reducing regional disparities and maintaining environmental sustainability in a region requires a development strategy (Dody, 2003). One effort to equalize economic growth is to accelerate regional economic development, especially underdeveloped areas, by empowering actors and the regional economic potential which is in line with the implementation of regional autonomy. Efforts to accelerate rural economic development based on the utilization of natural resources should pay attention to the harmony between the development sector, the environment, and the settlements feasibility under regional infrastructure.

The village development program remains an important priority because villages are struggling with poverty, limited basic facilities and infrastructure, and the scarcity of economic and social institutions. This condition is inseparable from the various problems and constraints faced by rural communities, such as: the low education of rural communities, the difficulty of access to capital, the low added value of agricultural businesses, the low level of control of agricultural land by farm households, the high dependence on agricultural cultivation activities, and the weak economic linkages between the agricultural sector and the industrial and service sectors, etc.

Based on the concept of development (community-based) proposed by Hasbullah (2006), the success of community development are determined by community capitals: (a) Human capital in the form of personal abilities such as education, knowledge, health, expertise and other related conditions; (b) Natural Capital such as land resources; (c) Produced Economic Capital in the form of economic, financial assets, and other assets; and (d) Social Capital in the form of norms (values, trust, reciprocity, other social norms), participation in networks, pro-activity.

Regional development cannot be realized without changes in social organizations and value systems. The productivity of an economic system and resource management are conditioned by the culture and institutions that exist in society (Hayami, in Rustiadi, 2011). Therefore, the community welfare level in an area is not merely to be interpreted as the level of economic growth, productivity, and material advancement. It ought to consider the community socio-cultural performance such as social interaction, access to income, education, health and democratic processes (Rustiadi, 2011). 
Several relevant works of literature suggest that human capital, natural resource capital, and productive economic capital have been widely worked on by the government. Nevertheless, social capital has been largely ignored (Cernea, 1988; Hasbullah, 2006; Jamasy, 2004; Rustiadi, 2011). The study of the correlation between social factors and regional development performance in a measured manner / quantitatively was introduced by Putman's (1993) research on the role of social capital in the regional economy.

Cibulao Hamlet, Tugu Utara Village, Cisarua District, Bogor Regency, Indonesia, is an intriguing example of endeavor to develop community independence while paying attention to the development of social capital. Cibulao Hamlet is located in Cultivation Right (HGU) land owned by PT Sumber Sari Bumi Pakuan (SSBP). Hence, the effort to empower the community requires a unique approach. Cibulao Hamlet is located in Tugu Utara village, Cisarua district, Bogor regency. Geographically, Cibulao Hamlet is located in a tea plantation area and is surrounded by forest areas managed by Perhutani (state-owned forestry enterprise). Tea plantations have existed since the Dutch colonial era (1811) which is known as the Ciliwung tea plantation.

Part of the Cibulao Hamlet community earns low wages which value is under the Bogor Regency UMR (Minimum Wages). Wages obtained depend on the number of tea leaves collected, low human resource capacity (due to lack of basic service facilities such as education, hence most only graduated elementary school), minimal health facilities, companies do not provide health insurance to employees and do not pay attention to settlements. These factors eventually damage plantation area and caused the following issue: poverty, low welfare level, floods, illegal logging, and cultivating vegetable illegal in the Perhutani area.

This study endeavor to determine the role of social capital in Cibulao Hamlet in improving the community's economy. This study used explorative and descriptive methods in order to determine the community socio-economic condition in Cibulao Hamlet.

Social Capital. Defining social capital that was presented by experts including Pretty and Ward (2001) identified four main aspects of social capital, namely: (a) the relationship of trust, (b) the reciprocity and exchanges, (c) common rules, norms and sanctions; and (d) connectedness, networks and groups. The key components of social capital identified by Putnam (1993), Fukuyama (1995), and by Knack and Keefer (1997) are (1) networks of civic engagement, (2) norms of generalized reciprocity and (3) social trusts. Based on the game theory model used by researchers, the repeated interactions in the network container, especially the horizontal network, will gradually lead to an increase in equivalent status and power, norms are grown and maintained with various forms of modeling and socialization (including civic education), and with sanctions (Putnam, 1993).

By its nature social capital (1) does not run out when used, otherwise, it will run out if not used, (2) not easily observed and measured, and (3) difficult to be built with outside intervention. Therefore social development is a development process using a different approach to physical development and is unique to each characteristic of different communities and regions. However, understanding the aspects and elements of social capital will determine the pattern of social development approaches needed (Rustiadi, 2011).

The more social and cultural character of the community that leads to bridging social capital can be interpreted as the socio-cultural condition. It supports the success of a development and vice versa. In regional development implementation, typology of social capital indication is needed to monitor community-based development programs. The programs were conducted in an endeavor to form a participatory and independent community (Pontoh, 2010). The socio-cultural character that characterizes the social capital in the community is determined through an approach to internal and external factors that influence society culture (Jamasy, 2006 in Pontoh, 2010). Internal factors include: (a) Patterns of social organization in a community that include local beliefs, patterns, production, and reproduction method, as well as local politics; and (b) the norms and values inherent in the community. The external factors are the influence of religion, education, system,s and political relations with government outside the community. 
Elements of social capital consist of (1) mutual trust (2) Norm, and (3) Networking. The relationship of trust will nurture cooperation, which can then reduce transaction costs between people and ultimately will save the use of resources. As a result of mutual trust, there is a little need to monitor others. Thus the relationship of trust will save money and time. In fact, the trust will build a sense of responsibility and a sense of appreciation, which will then lead to trust. In turn, the other party would reciprocate the trust, hence forming a reciprocal trust. There are two types of trust: the relationship of mutual trust with known individuals (thick trust); and the relationship of trust with strangers. The trust is directed to known social structures (thin trusts) (Rustiadi, 2011). Building trust requires a very long time but is often easily destroyed (Fukuyama, 1995), and when a society experiences distrust, building cooperation and arrangements will be difficult to materialize (Baland and Platteau, 1998).

A norm is a form of reciprocal agreement that effectively regulates behavior in such a way that group interests are placed above personal interests. The existence of general rules, norms, and sanctions make individuals believe that investing in collective or group activities, and trusting others will do the same. Individuals will fulfill their responsibilities with the belief that their rights will not be marginalized because there is mutual agreement on imposed sanctions. Formal rules are made by authorities, such as legal and regulatory products, while informal rules are used by individuals for various individual activities in daily life (Rustiadi, 2011).

Based on networking elements, social capital is divided into three types: (1) social capital bonding; (2) bridging social capital and (3) linking social capital. Bonding social capital is characterized by strong ties (relationships) such as between family members or between members in certain ethnic groups. Some views equate this bond with thick trust, which is social capital that is built up due to trust between groups of people who know each other. The second type, bridging social capital, is characterized by the increasing number of ties between groups such as business associations, relatives, friends from various different ethnic groups. This second type of social capital is built from thin trust, trust in a group of strangers. Whereas linking social capital is characterized by the relationship between different levels of strength and social status, such as interrelationships between political elites or between individuals from different classes.

Warner, 2001 in Rustiadi, 2011 presents aspects of social capital in the following areas: (1) "form" (whether horizontal or hierarchical), (2) "level" (individual/family level or community level) and ( 3 ) "investment costs". The form of social capital can be horizontal or hierarchical. Horizontal forms of social capital can encourage the involvement of more individual bonds in the community, encourage equality (egalitarian relations), and develop a more robust democratic structure (Putnam, 1993a, 1993b). The form of hierarchical social capital results in patron-client relationships (and groups) which may weaken development (Duncan, 1992; Putnam, 1993a; Portes and Sensenbrenner, 1993 in Rustandi, 2011).

The social capital can be divided into several levels: individuals, families, communities, local communities, communities in a region, national, and global level. Several studies on social capital focused at individuals or families level especially regarding the contribution of social capital to the individual economy and education development (Coleman, 1988; Bordieu, 1986 in Rustiadi, 2011). Putnam's research (1993a) explored social capital at the community level. Social capital at the community level cannot be measured only as a form of aggregation of individual networks. Particular attention needs to be given to interorganizational networks and government institutions. Social capital at the community level is determined by existing community groups and networks (Woolcock, 1998). Strong community social capital will create a "civic infrastructure" that will support the processes of decision making and public involvement both formally and informally (Potapchuck et al., 1997) (Rustiadi, 2011).

Individual social capital Investment requires immediate returns. On the other hand, the community level investment expects generalized reciprocity and democratic responsiveness from the government. The balance between autonomy and strong horizontal linkages strengthens generalized reciprocity and democratic government. Thus, regions with higher 
horizontal social capital will provide a good environment for increasing social capital investment.

Human activities in processing natural resources take place through individual or collective activities. Therefore, local institutions is always an effective element, because its existence allows resource utilization by minimizing repeated and negotiation processes and providing cheap prices (Bromley, 1993). Social capital will reduce the cost of cooperating and facilitating cooperation. People believe that investing in collective activities would encourage others to conduct in a similar manner and be motivated to abandon exclusive personal habits with negative influence, such as resource degradation. However, the effort provided to grow social and human capital is minimal.

Cibulao Hamlet Social Capital. The Cibulao community is formed from a group of families who work on tea plantations owned by PT. Sumber Sari Bumi Pakuan. For many years the mindset of the Cibulao community experienced no change. They prefer to work as plantation workers. These conditions resulted in lower living standards compared to the community's expectation. This is reflected in children education, as very few obtained education level above elementary school. In addition, long distance and expensive living cost discourage efforts to obtain a higher level of education.

Nevertheless, the new generation comes with a new spirit. They believe that the lifestyle ought to be improved instead of relying on income as plantation workers. They also prepare the best for future generations. For this reason, generations (3rd generation) are just starting to improve in an endeavor to develop existing potential. These potentials may become alternative livelihoods to improve the community living standard. They understand that the environmental resources around Cibulao Hamlet are very rich. This awakening is due to strong social capital which had been nurtured for a long time in the community.

The majority of Cibulao people work as permanent employees such as foremen and factory security workers. They also work as daily laborers such as tea pickers, pest sprayers, cultivators in PT. Sumber Sari Bumi Pakuan tea plantation. The Cibulao community raises livestock and utilizing PT. Perhutani land through Community Forest Management (PHBM) activities, namely the cultivation of coffee plants managed by the Cibulao Forest Farmers Group (KTH).

In 2009 the Forest Farmers Group (KTH) of Cibulao Hijau was founded in collaboration with Perhutani through the Community-Based Forest Management (CBFM) program. This program carries out coffee planting among Perhutani's forest stand (pine). Since PHBM program began in 2012, public interest in clearing the forest ceased. In 2015, through KTH and PHBM programs, more people were cultivating coffee among forest stand. In addition to economic added value, it could be used as an instrument to maintain forest sustainability.

KTH Cibulao Hijau was successful with the development of PHBM. This is reflected in the establishment of KTH Bike Park in 2013 by opening cycling paths that crossed production forests, tea gardens, and its surroundings. KTH Bikepark was considered successful. Cycling paths for AM class trail expert, XC and Enduro were developed a year after. In 2014 the inclusion of the IPB P4W consortium encourage changes in the community. P4W Consortium donated high-quality coffee cultivation and knowledge on cultivating coffee. In addition to increasing community income, this activity preserves the forest as well. P4W Consortium assistance is considered to be successful. It is reflected in high-quality coffee cultivation. Cibulao coffee won the first rank in national coffee competition for robusta types in 2016.

As Robusta Cibulao coffee was recognized at the national level in 2016 and successful KTH Bikepark development, Cibulao Hamlet was increasingly exposed. It began to be visited by many government agencies, both central and local governments, providing good contribution to Cibulao Hamlet. In $2016-2017$, Cibulao Hamlet received assistance in the form coffee seeds and sengon trees by the Livestock and Plantation Office and LIPI.

The development of the Forest Farmers Group (KTH) Cibulao encourages the development and formation of other community groups. The existence of these community groups can be seen in Figure 1. 


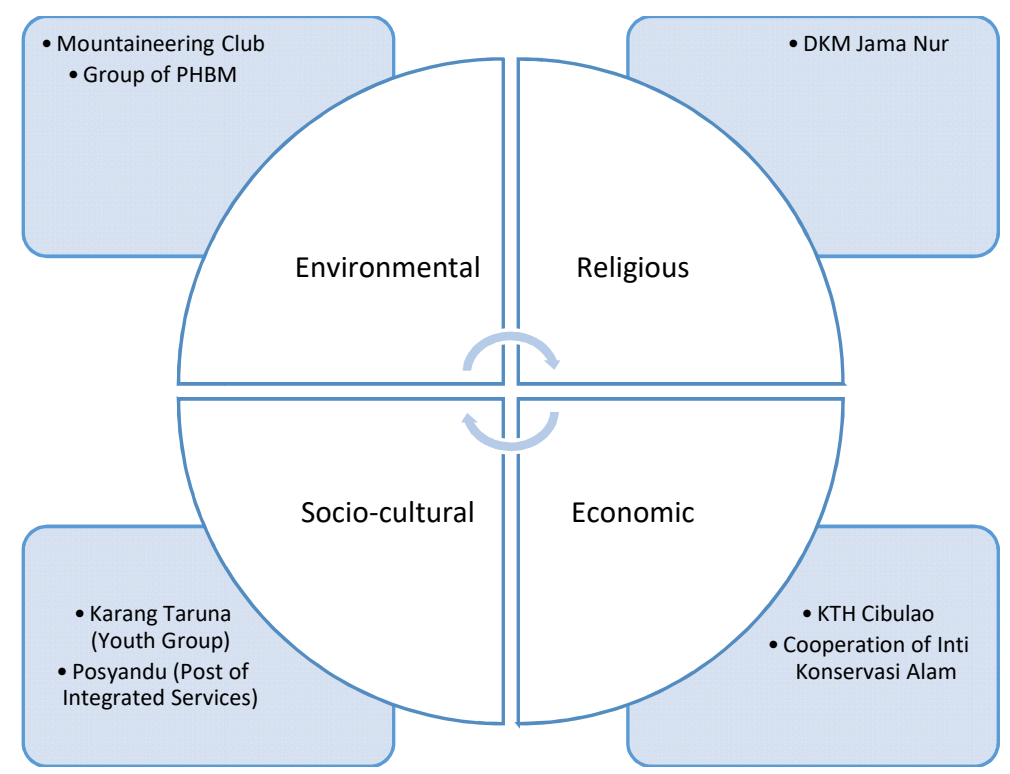

Figure 1 - Community groups developed after the Forest Farmers Group

Based on the level of social capital available in Cibuloa Village, it exhibits that:

- At families and community level, it bridges institutions related to Perhutani and the local government, good relationships are social capital;

- At the National level of inter-sectoral relations, there's existing sectoral ego and free riding;

- At Individual level, someone dares to take risks to bear their own costs for his or her respective investment.

Based on the elements of social capital (beliefs, norms, and networks), the social capital formed in Cibulao Hamlet is as follows:

a. Trust: Unity among fellow members and the community; Mutual trust; Protection of resources (eg trees); Shared rules obeyed by members; Existing initiator; Contributions; Mutual Cooperation.

b. Norms: Regular 2 weeks meeting; Forest monitoring patrol; Cycling Path Maintenance; Maintaining Coffee Plants.

c. Networking: Establish cooperation with the Village Government; Cooperating with PTPN 8 Gunung Mas; Cooperating with Bike Hobbyist Community; Cooperating with P4W IPB, PT SSBP, PT Perhutani, Agriculture Office, Penyelamatan Puncak Consortium, Bogor $\mathrm{KPH}$, FWI, ICCTF, Ranin Coffee House, Bogor Ciliwung Caring Community, INFIS, Ciliwing Institute, Kaoem Telapak, PT ANTAM, BP DAS.

\section{CONCLUSION}

Nature-based business development carried out by the Cibulao community, directly causes a socio-economic shift in society. The social economic shift is not visible and there is no supporting data. However, Cibulao Community attitudes and thought processes have begun to change. They sought alternative jobs. The socio-economic shift is reflected in the number of people who invest their business.

With the occurrence of socio-economic shifts, the community did not cause their culture and social capital to fade. There is no change to their lifestyle as the community still inhabit the plantation workers' residential areas. Therefore boasting wealth is an unusual conduct. The social capital formed in Cibulao Hamlet can gradually improve the community economy in. This is indicated by the increasing number of people who are interested in becoming members of Cibulao KTH and the growing businesses in Cibulao Hamlet. 


\section{REFERENCES}

1. Agus, D. S. 2003. Perencanaan Pembangunan Partisipatif Kota Solo, Pendekatan Pembangunan Ngwwongke-Uwong. Solo: Penerbit IPGI.

2. Hasbullah, J. 2006. Social Capital (Menuju Keunggulan Budaya Manusia Indonesia). Jakarta: Penerbit MR-United Press.

3. Nurzaman, S. 2012. Perencanaan Wilayah Dalam Konteks Indonesia. Bandung: Penerbit ITB.

4. Pontoh, O. 2010. Identifikasi Dan Analisis Modal Sosial Dalam Rangka Pemberdayaan Masyarakat Nelayan Desa Gangga Dua Kabupaten Minahasa Utara. Jurnal Perikanan dan Kelautan Tropis, Vol. VI-3, December 2010.

5. Putra, R. A. R., Ariyadi, B., Kurniawati, N., \& Haryadi, F. T. 2017. Pengaruh Modal Sosial Terhadap Tingkat Kesejahteraan Rumah Tangga Peternak: Studi Kasus Pada Kelompok Peternak Ayam Kampung Ngudi Mulyo, Gunungkidul. Buletin Peternakan Vol. 41 (3): 349-354, ISSN-0126-4400.

6. Rustiadi, E., Saefulhakim, S. R., Panuju, D. 2011. Perencanaan dan Pengembangan Wilayah. Jakarta: Penerbit Crestpent Press dan Yayasan Pustaka Obor Indonesia. 